\title{
Percepção Do "DNA" Da Marca Hering No Ponto De Venda Físico (Lojas)
}

\author{
Perception Of Hering's "DNA" Brand At The Point Of Sale \\ (Stores).
}

\author{
Cinthia Ferrari Angeli \\ Mestre, Universidade Federal de Santa Catarina \\ cinthia.arqurb@gmail.com \\ Luiz Salomão Ribas Gomez \\ Doutor, Universidade Federal de Santa Catarina \\ salodesigner@gmail.com
}




\title{
Percepção Do "DNA" Da Marca Hering No Ponto De Venda Físico (Lojas).
}

Perception Of Hering's "DNA" Brand At The Point Of Sale (Stores).

Cinthia Ferrari Angeli, Luiz Salomão Ribas Gomez

\section{Resumo}

Este artigo visa demonstrar a importância e a necessidade de inserir o "DNA de marca" no projeto de arquitetura de interiores comercial. São raros os materiais teóricos nesta área, que abordam a importância de desenvolver projetos de ambientes comerciais mais ajustados com o "DNA da marca". "DNA" este que é formado por elementos que combinam e se recombinam para expressar diferentes identidades. O objetivo foi demonstrar através da aplicação de um questionário, quais aspectos da atmosfera do ponto de venda, diante da percepção dos usuários, apresentavam-se mais condizentes ao "DNA de marca" da Cia Hering. Os apontamentos identificaram de forma geral que os usuários percebem o "DNA da marca" no ambiente e no produto. Entretanto, alguns elementos especíicos da atmosfera do ponto de venda apresentaram ressalvas.

Palavras-chave: DNA de marca, arquitetura comercial, visual merchandising

\begin{abstract}
This article aims to demonstrate the importance and the need for inserting the "brand DNA" into the architectural project of commercial spaces. Theoretical reference is rare in this area. Therefore, there is the importance of developing projects in commercial contexts that are more attuned to the "brand DNA", which is formed by elements that may be combined and recombined to express different identities. The goal of this study was to demonstrate, through the application of a questionnaire, which aspects of the atmosphere of the point of sale in two different stores were coherent with the "brand DNA" of the company Cia Hering - from the perspective of both the employees and consumers. Users generally identified the "brand DNA" both in the environment and in the product. However, some specific elements of the atmosphere of the point of sale presented reservations in addressing the brand DNA.
\end{abstract}

Keywords: DNA brand, commercial architecture, visual Merchandising 


\section{Introdução}

Cada vez mais a competitividade do mercado impulsiona os empresários do setor comercial a investirem no planejamento estratégico dos pontos de venda físicos (PDV). A qualidade do ambiente comercial adquire grande importância para o sucesso de um empreendimento, uma vez que na maior parte das circunstâncias é o PDV que possibilita o acesso do cliente ao produto. Portanto, todos os elementos que compõem a atmosfera do ponto de venda, como: layout, materiais de acabamentos, iluminação, mobiliário, entre outros, serão determinantes na experiência de compra.

Para Bardzil e Rosenberger (1996), a atmosfera do ponto de venda é mais influente que o próprio produto na decisão da compra, e, assim sendo, deve haver um esforço intencional do comerciante para impactar e atrair o consumidor. Alguns estudos na área de Psicologia Ambiental evidenciaram que o ambiente causa efeitos emocionais nos usuários, podendo contribuir para sua aproximação, ou para seu afastamento em relação ao local (Mehrabian; Russel, 1976).

Desta forma, diante das constantes inovações e "infidelidade" por parte dos consumidores, a arquitetura cumpre um papel importante no cotidiano do varejo e exerce grande influência nos processos de consumo. $O$ arquiteto é responsável por um projeto comercial estratégico que envolva o consumidor e o induza no processo de compra através de todos os elementos que compõe a atmosfera do ponto de venda baseado no "DNA de marca". "DNA" este que é responsável pelas características singulares de cada marca.

Para Carvalhal (2014), é de olho nessas singularidades inscritas em cada uma das marcas que muitas pessoas encontram na moda um caminho para estabelecer e criar a sua própria identidade.

Neste sentido, o planejamento do ambiente comercial e do visual merchandising deve ser coerente com o "DNA da marca", atendendo as expectativas de seus usuários e stakeholders, com o intuito de contribuir efetivamente no processo de compra.

A respeito da importância da percepção do "DNA de marca" no ponto de venda, há poucos estudos na área de arquitetura de interiores comercial no Brasil. $O$ objetivo deste trabalho é demonstrar a percepção do "DNA de marca" nos elementos que compõe o projeto de arquitetura comercial no PDV físico de um segmento de 
moda, buscando entender quais aspectos da atmosfera de venda, perante os seus usuários - funcionários e consumidores, traduzem ou não o "DNA" da marca.

Os resultados deste artigo provem de estudos de caráter dissertativo apresentado ao Programa de Pós-Graduação de Arquitetura e Urbanismo da UFSC - PósARQ.

\section{Revisão bibliográfica}

\subsection{Marca e DNA de marca}

O rápido desenvolvimento global permite que cada vez mais sejam oferecidos produtos similares e competitivos ao mercado, apresentando as mesmas especificações técnicas, e qualidades semelhantes, o que de certa forma elimina ou reduz os seus diferenciais físicos. Neste sentido, além da constante atualização dos produtos, as empresas têm buscado apresentar sua identidade em todos os pontos de contato com a marca, reforçando seu "DNA", a fim de evitar serem confundidos. Desse modo, os consumidores também passaram a buscar mais que um produto e um logotipo. O consumidor de hoje procura por experiências, valores e significados.

Ries e Trout (2009, p.19) acreditam que "[...]o mercado de hoje já não reage mais às estratégias que deram certo no passado. Há produtos demais, empresas demais e barulho de marketing demais. "

Para compreender especificamente sobre marca, Kotler (2006), define como um produto ou serviço que agrega dimensões que de alguma forma 0 diferenciam de outros produtos ou serviços desenvolvidos para satisfazer a mesma necessidade. Sobre a escolha de uma determinada marca, existem vários fatores que influenciam. O importante é identificar os pontos que podem contribuir para 0 seu crescimento como marca e no aumento das suas vendas, sendo a apresentação clara e definida do "DNA" um deles.

A todo momento marcas entram e saem do mercado, há uma seleção natural, que se dá por nível de relevância. Para continuar relevante, uma marca precisa estar viva. Pois assim como o ser humano, uma marca nasce, cresce e escreve a sua história (Carvalhal, 2014).

Assim, no que se refere, ao termo "DNA de marca", o mesmo pode ser compreendido tal qual o "DNA" de um ser vivo, em que este, é responsável pelo armazenamento das características genéticas de cada indivíduo. (Nowrah, 2006 apud Stodieck, 2014). 
"O DNA das organizações vivas compõe-se de quatro elementos básicos, que se combinam e recombinam para expressar distintas identidades ou personalidades" (Neilson; Pasternack, 2010, p. 10). Desta forma, através dos significados de uma marca se tem um DNA próprio da empresa, que a difere de todos os outros empreendimentos assim como um ser humano (figura 1).

Para compreender o "DNA de marca", o laboratório de Orientação da Gênese Organizacional da Universidade Federal de Santa Catarina (LOGO UFSC), desenvolveu uma metodologia TXM Branding, que resumidamente tem como foco a gestão da imagem das empresas e que consiste em apresentar soluções mais assertivas, com resultados mais eficientes e satisfatórios, tanto para os agentes internos da empresa (marca) quanto para os externos a ela.

A metáfora "DNA de marca" (figura 1) assim como o DNA do ser vivo, possui em sua estrutura quatro elementos de diferenciação: Emocional, Mercadológico, Técnico e Resiliente, que combinados entre si terão uma característica única perante seus consumidores. No caso do "DNA de marca" o conceito integrador faz o papel da ligação entre os elementos, assim como a cadeia de fosfato faz no DNA orgânico.

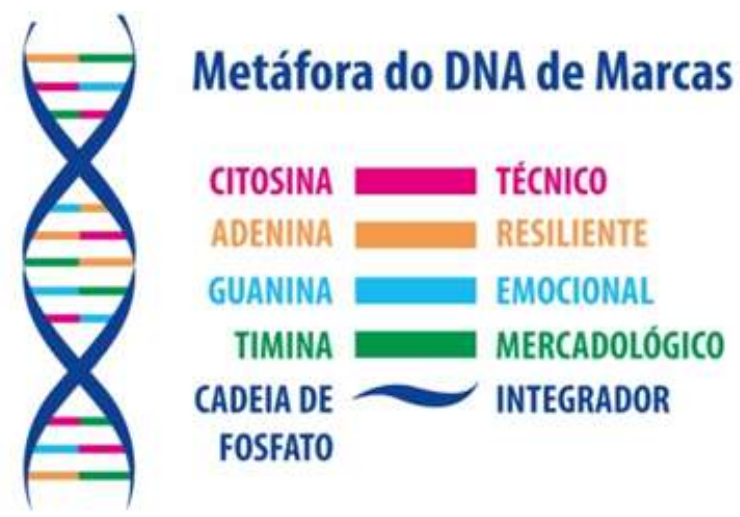

Figura 1: Componentes do "DNA" de marca. (LOGO - UFSC, 2015).

Para entender como funcionam os elementos de "DNA de Marca", Lopes e Gomez (2012) descrevem cada um deles: o elemento técnico está diretamente ligado ao produto ou serviço que a organização oferece. Ele corresponde as qualidades mais técnicas, transmitindo a tangibilidade da marca ao consumidor.

No que se refere ao elemento resiliente, significa como a marca irá manter a autenticidade dentro das frequentes mudanças da sociedade de consumo. Neste caso, uma marca deve ser capaz de se atualizar constantemente em busca 
de uma construção contínua. Sobre o elemento emocional, este tem como função, aproximar a marca aos aspectos decisórios de fidelização do consumidor, conforme Lopes e Gomez (2012).

Já o elemento mercadológico refere-se à forma como a marca irá se apresentar ao mercado. Ligado à postura que a marca assumirá perante a concorrência. Desta forma, é o elemento que representa o posicionamento estratégico da marca.

Por fim, o elemento integrador que conecta estes quatro elementos do "DNA", define a forma de agir da marca, recombinando-se quando necessário com o intuito de construir vantagem competitiva e assim fidelizar o cliente. Estes elementos cada marca já possui. É através deles que as marcas se diferenciam perante as concorrentes.

Para Stodieck (2014), uma empresa que queira se destacar e permanecer na lembrança das pessoas necessita gerar experiências marcantes, e que estas estejam de acordo com o "DNA de marca" e os valores que a mesma acredita.

\footnotetext{
Estes valores devem ser encontrados em todos os pontos de contato da marca, seja na forma de atendimento, seja na sua assinatura gráfica, nas ações publicitárias ou em qualquer outro ponto que ligue a marca as pessoas. (Stodieck, 2014, p.52)
}

Segundo Gomez e Prestes (2010), ao se identificar o "DNA" de uma empresa, consegue-se reunir as informações necessárias para criar experiências significativas nas interações estabelecidas com a marca. Essas experiências vão além do contato com o produto, e podem ocorrer desde a concepção deste, até a interação de compra com o cliente na atmosfera do ponto de venda.

\subsection{Atmosfera do PDV}

O estudo sobre a influência do ambiente físico comercial, no comportamento de compra dos consumidores vem se tornando "objeto" de interesse dos pesquisadores e profissionais envolvidos com o segmento de varejo. No que se refere ao ambiente físico, compreende-se como ponto de venda (PDV) "[...] qualquer estabelecimento comercial que exponha serviços ou produtos para a venda aos consumidores" (Blessa, 2008, p.52). Neste sentido podemos citar alguns exemplos, como supermercados, lojas, padarias, farmácias, bancas, lojas virtuais, entre outros. 
Um ponto de venda é caracterizado por uma atmosfera circundante. Sabe-se que existem diversos estudos para determinar os elementos que envolvem esta atmosfera. Neste sentido, o termo em si - atmosfera do ponto de venda, foi inserido por Kotler (1973-1974), para descrever as qualidades do ambiente físico da loja, qualidades estas utilizadas para criar certos efeitos emocionais específicos em seus consumidores. Segundo Kotler (1973-1974 p.49), tecnicamente atmosfera é "o ar em torno de uma esfera". O termo é utilizado para descrever que o ambiente físico reproduz sensações agradáveis, referindo-se a uma qualidade do espaço circundante. Conforme o autor os canais sensoriais da atmosfera são: visão, audição, cheiro e tato.

A partir do estudo de Kotler (1973-1974), o termo vem sendo utilizado e reformulado por diversos pesquisadores, para descrever a atmosfera dos ambientes comerciais. Baker (1986) classificou os componentes da atmosfera do ponto de venda como: Fatores Ambientais, Fatores de Projeto e Fatores Sociais. Os Fatores Ambientais estão relacionados às condições que afetam os sentidos humanos, como cheiro, música, temperatura, iluminação e som. Os Fatores de Projeto são referentes às características funcionais como layout e sinalização, e também as características estéticas como cor, materiais, escala e decoração. E os Fatores Sociais, que correspondem ao ser humano inserido no ambiente, a relação entre os funcionários e os clientes.

Bitner (1992) também classificou os itens que compõe a atmosfera do ponto de venda em: Condições Ambientais, Layout e Funcionalidade, Símbolos, Sinais e Artefatos. As Condições Ambientais são descritas como música, temperatura e iluminação. Funcionalidade e Layout se referem ao mobiliário, sua distribuição e sua capacidade de facilitar o serviço. E os Símbolos, Sinais e Artefatos que representam e comunicam a empresa através da decoração, materiais e símbolos.

Autores como Blessa (2008), Cobra (2009) e Solomon (2011), sintetizam a atmosfera em poucos elementos (tabela 1). Blessa (2008) acredita que a atmosfera se refere ao design de um ambiente por meio de comunicações visuais, iluminação, cores, música e aromas.

Segundo Cobra (2009) em uma loja a atmosfera é fruto da ligação entre a apresentação externa e interna. E, sobretudo a ligação entre as soluções de layout, cores, sons, aromas e, os aspectos emocionais - pois neste ambiente deixa-se parte 
da economia mensal. O autor Solomon (2011) refere-se à atmosfera como design consciente do ambiente e de suas várias dimensões para evocar certos efeitos que estimulem a compra nos consumidores. Tais dimensões segundo autor incluem cores, sons e aromas.

\begin{tabular}{|c|c|c|c|c|c|}
\hline KOTLER (1973-1974) & BAKER (1986) & BITNER (1992) & BLESSA (2008) & COBRA (2009) & SOLOMON (2011) \\
\hline $\begin{array}{l}\text { VISÄO; } \\
\text { AUDIÇĀO; } \\
\text { CHEIRO; } \\
\text { TATO. }\end{array}$ & 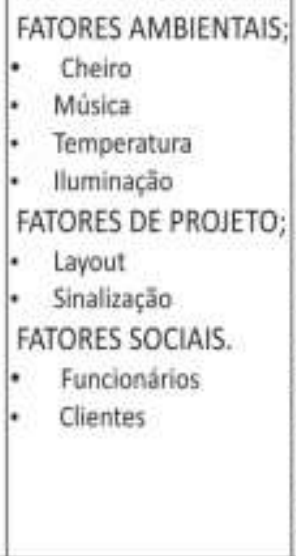 & 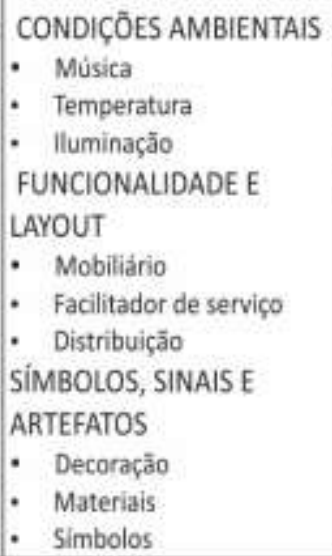 & $\begin{array}{l}\text { COMUNICAÇĀO } \\
\text { VISUAL; } \\
\text { ILUMINAÇĀO; } \\
\text { CORES; } \\
\text { MÚSICA. }\end{array}$ & $\begin{array}{l}\text { LAYOUT; } \\
\text { CORES; } \\
\text { SONS; } \\
\text { AROMAS. }\end{array}$ & $\begin{array}{l}\text { CORES; } \\
\text { SONS; } \\
\text { AROMAS. }\end{array}$ \\
\hline
\end{tabular}

Tabela 1: Síntese dos componentes da atmosfera do ponto de venda (Autores, 2015)

A preocupação em compreender e definir a atmosfera que circunda 0 ponto de venda por parte dos autores é notória. Todos os elementos que fazem parte desta atmosfera têm como objetivo principal atrair e fidelizar o consumidor. Porém Kotler (1973-1974), assim como Blessa (2008), ressaltam que é necessário compreender a percepção dos clientes, verificando e testando a imagem refletida pelos elementos que compõem o ambiente. O intuito é evitar erros, ou seja, ambientes desagradáveis, de imagens contraditórias aos valores da marca, atmosfera incompatível com os clientes, entre outros.

Neste sentido, se o ambiente da loja e os produtos se mostrarem com a mesma imagem e os mesmos valores da marca, solidifica-se a imagem da marca junto ao cliente. Sabe-se que os clientes estão cada vez mais exigentes e seletivos, o que obriga o setor comercial e as marcas a buscarem novas soluções a fim de fidelizar os consumidores (Zorrilla, 2002).

Os itens considerados relevantes com base na revisão bibliográfica e que compõe a atmosfera do ponto de venda, do ponto de vista da arquitetura de interiores, que podem vir a influenciar o ambiente, apresentam-se na figura 2: 


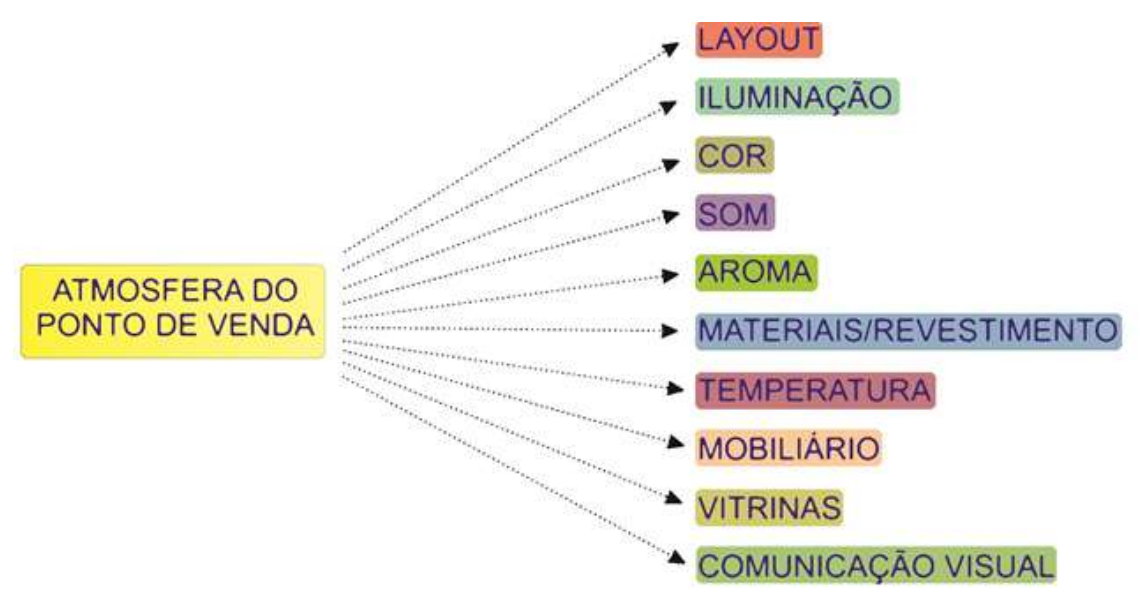

Figura 2: Alguns componentes da atmosfera do ponto de venda (Autores, 2015)

Solomon (2011) esclarece que os profissionais de marketing reconhecem que a imagem da loja é um aspecto muito importante e que os designers e arquitetos de lojas dedicam muita atenção para criar a atmosfera pretendida. Porém, o autor expõe que algumas lojas têm a imagem definida de forma muito clara, no entanto, outras tendem a confundir-se na multidão. Por isso, assemelhar-se ao DNA de marca nos pontos de contato, pode apresentar-se como um diferencial estratégico para a empresa, e destacar-se no mercado.

No ponto de vista de Morgan (2011), o design de uma loja pode contribuir para o fortalecimento da imagem da marca e desta forma apoiar uma estratégia comercial bem-sucedida. Enquanto alguns lojistas procuram por um projeto de design de lojas de forma mais simples, outros preferem inspirar o público com projetos impactantes. Os lojistas acreditam que o design da loja pode estimular os consumidores a entrarem no estabelecimento. Sobretudo, o principal objetivo do projeto de uma loja é apresentar os produtos da melhor forma possível, através de uma combinação de funcionalidade, ambiência e design de interiores convidativo. Cada loja é singular e suas características devem estar de acordo com o tipo de produto que é oferecido.

Sabe-se que o papel do arquiteto é essencial neste contexto. A atuação deste profissional em conjunto com outros profissionais de diversificadas áreas, será determinante na elaboração do projeto arquitetônico do ponto de venda. Este por sua vez, passará a partir dos elementos que compõem essa atmosfera a refletir os valores e a identidade pretendida pela empresa ao seu cliente. 


\section{Metodologia}

Na presente pesquisa será investigada a relação entre a Marca de moda Hering $x$ Ponto de venda $x$ Usuários, por se entender que é fundamental no sucesso de um estabelecimento comercial, refletir no ponto de venda as características que envolvem uma marca e compreender como elas são percebidas.

Trata-se de uma pesquisa de natureza qualitativa e exploratória, no que se refere às etapas de pesquisa bibliográfica. De acordo com Gil (2008), o objetivo é proporcionar maior familiaridade com o problema, a fim de torná-lo mais explícito.

Optou-se ainda por um estudo em campo, em estabelecimentos de varejo de moda (lojas), a fim de explanar situações reais. Desta forma, é possível avaliar através dos estudos da referência bibliográfica, a percepção do consumidor em relação aos elementos arquitetônicos do ponto de venda e sua relação com o "DNA de marca".

A presente pesquisa está dividida em:

a. Revisão Bibliográfica;

b. Descrição dos métodos e abordagens: visitas exploratórias, caracterização, levantamento espacial e fotográfico do ambiente comercial, caracterização da marca e questionários;

c. Preparação dos instrumentos metodológicos para o trabalho de campo;

d. Análise, tratamento e discussão dos dados e resultados obtidos.

Para análise dos questionários, em um primeiro momento houve a leitura e organização destes. Por seguinte, foi realizada a transcrição dos dados para um software, neste caso o Excel. Após transcrição dos dados, iniciou-se o processo de categorização. Com as respostas cedidas pelos consumidores, foi possível primeiramente criar subitens, que posteriormente se agruparam e viraram uma única categoria. Após esta etapa, iniciou-se o processo de tabulação de dados.

Por se tratar de um artigo, somente será apresentado um quadro síntese com os principais resultados encontrados.

\subsection{População e amostra}

Conforme Minayo (1992), a pesquisa qualitativa não se baseia no critério numérico para garantir sua representatividade. O fator relevante neste caso é compreender quais indivíduos sociais tem uma vinculação mais significativa com o 
problema que está sendo investigado. Neste caso, por tratar-se de um trabalho que busca compreender a percepção da imagem representada no ambiente comercial, entende-se que não há um perfil ideal de sujeito, suas características pessoais como idade, gênero e nível de escolaridade, não são importantes como critério de seleção. O que se torna relevante neste caso, é que os entrevistados sejam clientes e que de fato efetuem compras no ambiente. Este critério se estabelece, por acreditar, que indivíduos com esse comportamento, tenham um olhar mais apurado do ponto de venda, pois de certa forma, já estão familiarizados com o ambiente.

A população desta pesquisa pode ser dividida em dois grupos, de acordo com suas atividades: funcionários e consumidores das lojas analisadas.

No que se refere ao número da amostra, ao todo foram analisados 80 questionários.

\subsection{Objetos de análise}

$\mathrm{Na}$ presente pesquisa optou-se por estudar lojas de moda de vestuário, considerando que este segmento é predominante na área do varejo.

Contatou-se, então, empresas do setor de moda. Em decorrência, um franqueado da empresa Cia. Hering, se mostrou solicito em participar da análise. $\mathrm{O}$ mesmo, disponibilizou suas oito franquias da rede com lojas de vestuário feminino e masculino, situadas em na região sul, no estado de Santa Catarina, sendo que destas, foram selecionadas duas, devido à proximidade das lojas com viés diferentes: um ponto de venda de rua e um ponto de venda de shopping.

Acredita-se que as diferenças na localização das franquias e suas particularidades ambientais, poderão ser encontrados resultados mais abrangentes e aprofundados, contribuindo para uma pesquisa de melhor qualidade.

\section{Aplicação dos instrumentos e abordagens}

Para resultados satisfatórios, nesta etapa da pesquisa, foram realizadas visitas exploratórias, levantamento espacial e fotográfico das lojas em análise, caracterização do ambiente e da marca, entrevista com o proprietário dos pontos de venda e conversas informais com as gerentes das respectivas lojas e a consultora de franquias regional. 
Diante do vasto número de informações, priorizou-se neste artigo, como mencionado, apresentar o resumo dos resultados provindos de questionários, aplicados com funcionários e clientes das lojas analisadas.

Neste sentido, deve-se ressaltar que os resultados sobre cada pergunta não serão apresentados e sim um quadro síntese sobre a percepção geral do consumidor referente ao DNA e os elementos que compõe o PDV analisado.

Sendo assim, o primeiro passo nesta etapa de aplicação dos instrumentos foi aplicar um pré-teste a fim de garantir fidedignidade ao instrumento de coleta, no caso os questionários. Após pré-teste, os questionários foram validados e iniciado a aplicação destes.

A aplicação foi realizada nas lojas A e B (ver tópico a seguir), durante o período de outubro a dezembro de 2016. Para coleta dos dados, a pesquisadora aguardava a colaboração da gerente e das caixas das lojas em análise, que abordavam o cliente no pós-venda, afim de captar consumidores que vivenciavam o ambiente de forma completa. Buscou-se este procedimento no intuito de diminuir qualquer tipo de importuno nas atividades dos funcionários, evitando prejudicar as vendas e desta forma alcançar a amostra esperada.

\subsection{Caracterização das lojas}

\section{a. Loja $A$}

É classificada como varejo de rua, significando que a mesma se encontra situada na via.

O ambiente de loja, que oferece vestuário feminino e masculino possui um único acesso e apresenta-se setorizado em feminino e masculino. No lado direito, em relação a entrada da loja, encontra-se posicionado o caixa da loja, os equipamentos do vestuário e os acessórios masculinos. O lado esquerdo corresponde aos equipamentos de vestuário e acessórios femininos (figura 4).

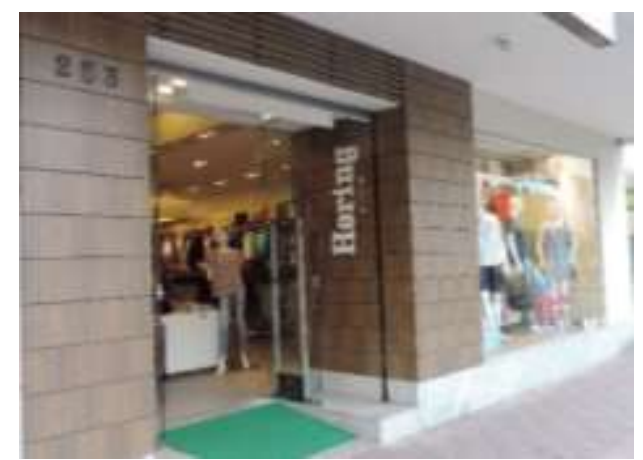

Figura 3: Fachada Hering Store - Loja A, vista da rua (Autores, 2016) 


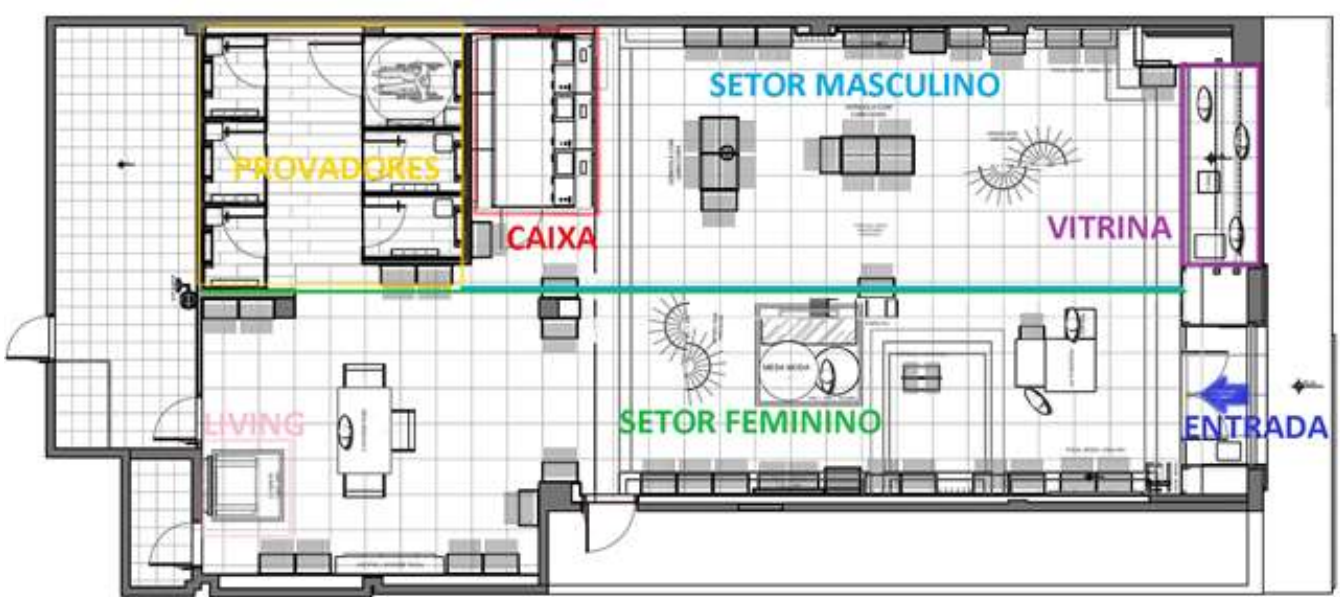

Figura 4: Planta baixa arquitetônica Hering Store - Loja A (Adaptada pelos autores de acordo com o fornecido pelo franqueado, 2016)

\section{b. Loja B}

Classifica-se como varejo de shopping (figura 5). E apresenta o mesmo padrão da loja de rua, dividindo-se em setor feminino e masculino. Comparando as duas lojas podemos observar através das plantas baixas que a loja B não apresenta uma área de living destinada aos seus usuários. Outra diferença é que na loja $B$ há dois espaços destinados a exposição de produtos, diferente da loja A que conta com um único espaço.

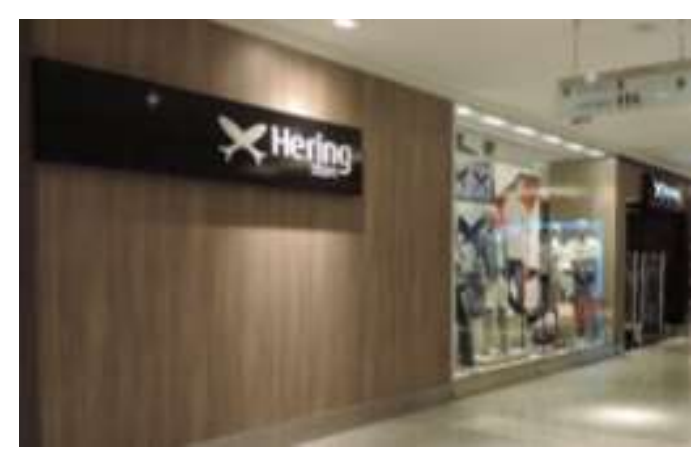

Figura 5: Fachada Hering Store - Loja B, Shopping (Autores, 2016) 


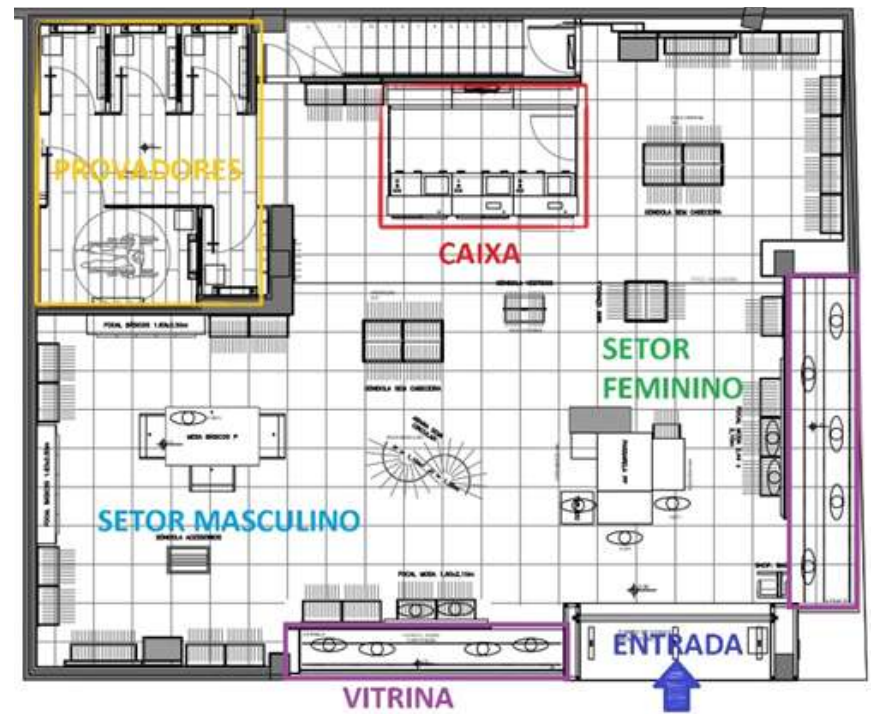

Figura 6: Planta baixa arquitetônica Hering Store- Loja B (Adaptada pelos autores de acordo com o fornecido pelo franqueado, 2016)

\subsection{Caracterização da marca}

Sabe-se que qualquer marca do setor de moda deve estar atenta e em constante atualização. Quando se tem um "DNA de marca" definido e aplicado a todos os pontos de contato, acompanhar essas mudanças torna-se mais fácil. Pois, deste modo, além de lançar novos produtos a empresa consegue transmitir seus valores e agregar significados tanto aos produtos como nas experiências, fidelizando e atraindo clientes.

No que se refere ao DNA da Cia. Hering, o Diretor de marcas da Cia., Edson Amaro', em entrevista concedida para a Revista Propaganda em janeiro de 2016, define como o DNA de uma empresa que se mantem em constantes atualizações. Amaro, acredita que o varejo atual é um mercado altamente dinâmico, e é de suma importância a inovação contínua. Ele afirma que ao longo dos anos foram feitas diversas atualizações na marca, mas que sempre foi mantido o "DNA" central da mesma.

Um exemplo de atualização é o logotipo da empresa (figura 7) que mantem sua essência e história desde a fundação de 1880, o símbolo em que traz na composição dois peixes (arenques) cruzados, é a tradução de Hering do alemão para o português, sendo que cada peixe e seu cruzamento representa a união dos irmãos fundadores da empresa.

O logotipo foi redesenhado segundo Amaro, com o intuito de modernizálo, retirando-se a elipse que os envolviam para demonstrar expansão e liberdade. E 
os peixes em si receberam novas proporções mais harmônicas e leves arredondamentos.

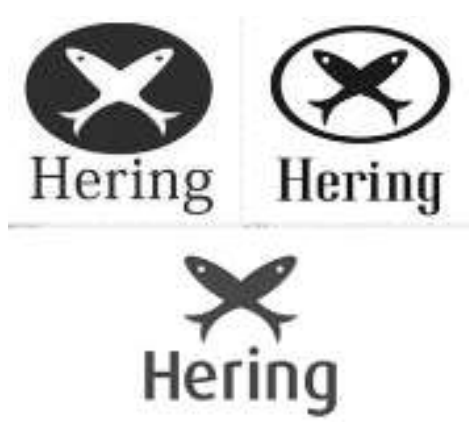

Figura 7: Evolução visual da Marca Hering (Mundo das Marcas, 2014)

Para Amaro, a marca evoluiu, mas os atributos permaneceram: "é uma marca democrática, confortável e cheia de brasilidade"

Segundo relatório anual da marca Hering (2015), o "DNA" da empresa é descrito como casual. Neste contexto, visando a compreensão, em consulta ao dicionário brasileiro da língua portuguesa, Michaelis (2016), a palavra casual significa algo que depende do acaso, que aconteceu por acaso, eventual, fortuito, ocasional.

Em explicação sobre o "DNA da marca" Hering, tanto o franqueado das lojas em análise, assim como uma consultora de franquias regional de Santa Catarina, em conversa verbal, comentou que o "DNA" casual está ligado ao comportamento do usuário, que no seu dia a dia independente do evento, deve encontrar na marca, roupas casuais que podem ser usadas tanto no trabalho, como em um evento a noite. É voltada para o público jovem, que tem no guarda roupa peças chave para qualquer situação.

No que se refere ao produto, a marca é conhecida pela sua linha de roupas básicas de malha.

Ainda, segundo o relatório anual, a marca é amplamente aceita por diversas classes sociais e faixas etárias em decorrência da oferta de produtos com boa relação custo $x$ benefícios.

Como este estudo trata principalmente da arquitetura no ponto de venda, sabe-se que este projeto é responsável por transportar o "DNA da marca" para o ambiente de vendas através da criação de uma atmosfera de compra. Buscou-se compreender todo o universo da marca e sua identidade, a fim de entender a percepção da imagem recebida pelo consumidor no ponto de venda, local de estudo e abordagem dos procedimentos metodológicos. 


\subsection{Resultados encontrados na Loja A e Loja B - Consumidor e Funcionário}

Após análise e tratamento dos dados, e afim de facilitar a compreensão dos resultados, é possível observar através do quadro síntese 2 e 3 , as percepções dos consumidores e funcionários, tanto na loja $\mathrm{A}$ como na loja $\mathrm{B}$. No primeiro quadro são analisados os aspectos gerais, e os demais quadros exibem a análise dos aspectos específicos de um ambiente de varejo de moda.

\begin{tabular}{|c|c|c|c|c|c|}
\hline \multirow{2}{*}{$\begin{array}{l}\text { ASPECTO } \\
\text { ANALISADO - } \\
\text { Geral }\end{array}$} & \multicolumn{2}{|c|}{ LOJA A } & \multicolumn{2}{|c|}{ LOJA B } & \multirow[b]{2}{*}{ COMENTÁRIOS } \\
\hline & Con. & Func. & Con. & Func. & \\
\hline $\begin{array}{c}\text { Percepçāo da } \\
\text { marca }\end{array}$ & & & & & $\begin{array}{l}\text { Percebeu-se através dos questionários, e } \\
\text { conversas informais que os consumidores e } \\
\text { os funcionários, apresentam uma } \\
\text { percepção positiva da marca. }\end{array}$ \\
\hline $\begin{array}{c}\text { Percepção do } \\
\text { produto }\end{array}$ & & & & & $\begin{array}{l}\text { O produto é o aspecto que mais se destaca } \\
\text { no ponto de venda. Apresenta uma } \\
\text { percepcão positiva diante dos seus } \\
\text { consumidores. }\end{array}$ \\
\hline $\begin{array}{l}\text { Percepçāo } \\
\text { sobre o } \\
\text { ambiente }\end{array}$ & & & & & $\begin{array}{l}\text { Assim como marca e produto, a percepção } \\
\text { sobre o ambiente da loja de forma geral é } \\
\text { agradável }\end{array}$ \\
\hline $\begin{array}{l}\text { História, } \\
\text { responsabilida } \\
\text { de social da } \\
\text { marca }\end{array}$ & & & & & $\begin{array}{l}\text { Sobre o envolvimento do consumidor com a } \\
\text { marca, em análise do método dos } \\
\text { questionários, mostrou que os } \\
\text { consumidores em maioria, não sabem qual } \\
\text { a historia e valores da marca. }\end{array}$ \\
\hline $\begin{array}{l}\text { Reconhece o } \\
\text { DNA da marca } \\
\text { através do } \\
\text { produto }\end{array}$ & & & & & $\begin{array}{l}\text { Diante do questionário, a maioria dos } \\
\text { entrevistados identificou o produto e a } \\
\text { marca como casual, conforme DNA } \\
\text { indicado pela empresa. }\end{array}$ \\
\hline $\begin{array}{l}\text { Reconhece o } \\
\text { DNA da marca } \\
\text { através do } \\
\text { ambiente de } \\
\text { forma geral }\end{array}$ & & & & & $\begin{array}{l}\text { De forma geral os consumidores } \\
\text { consideram que o ambiente das lojas } \\
\text { analisadas, refletem os aspectos da } \\
\text { identidade da marca. }\end{array}$ \\
\hline
\end{tabular}

Quadro 2: Síntese dos resultados referentes a percepção dos aspectos gerais do PDV (Autores, 2017) 


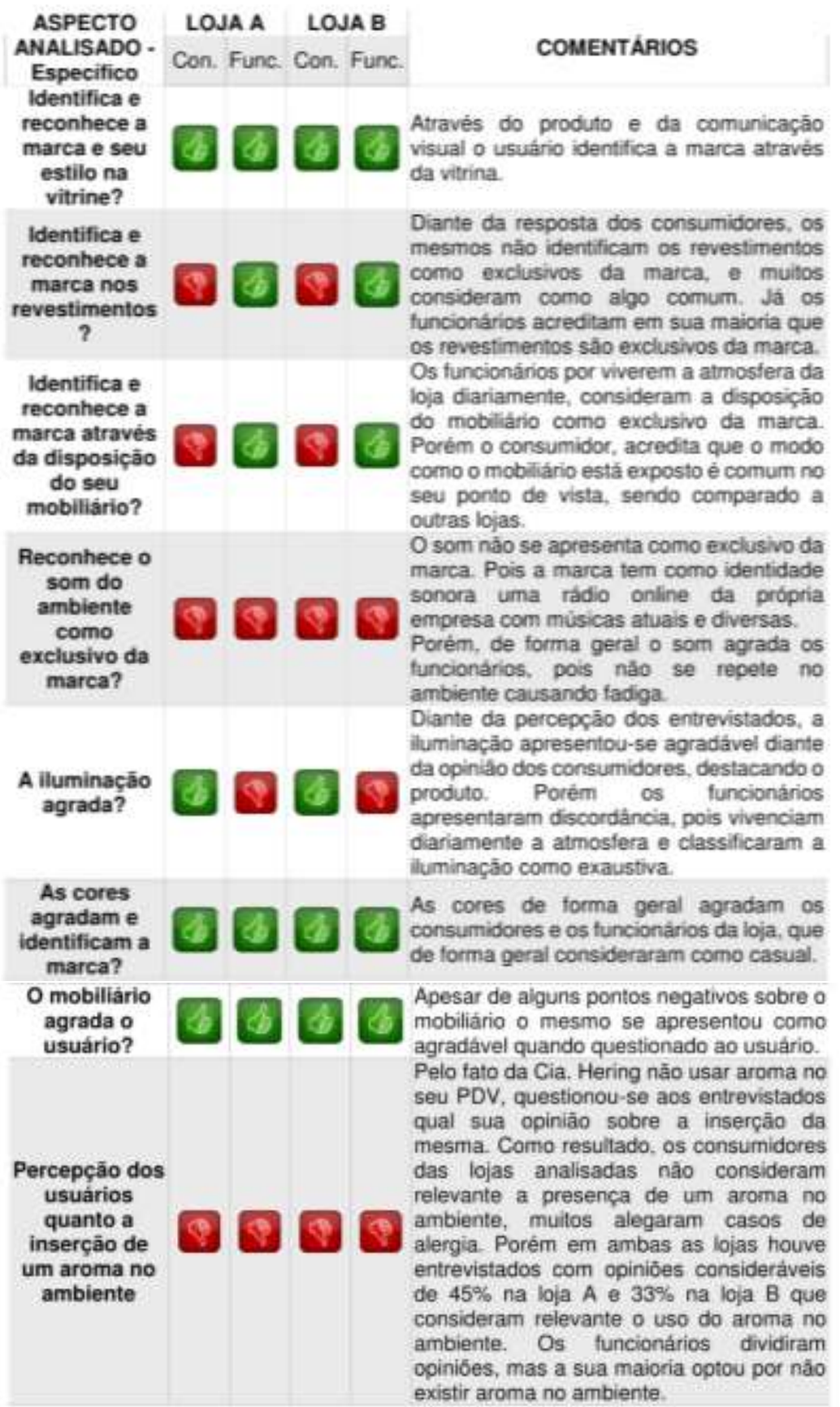

Quadro 3: Síntese dos resultados referentes a percepção dos aspectos específicos do PDV

(Autores, 2017)

Ao analisar as tabelas, percebemos que de forma geral, a marca é percebida positivamente pelo consumidor alvo. $O$ foco de qualquer planejamento de um ambiente comercial, neste caso, seu produto, dentro da atmosfera de loja é destacado no ambiente e percebido pelo consumidor. O ambiente apresentou-se diante dos resultados dos questionários, agradável para seus usuários e não foram evidenciados problemas críticos de arquitetura ou descaracterização da marca no ambiente de venda. Acredita-se que a marca tem um posicionamento assertivo no 
ambiente de loja, que está destinado ao público jovem e que busca produtos casuais para o dia a dia. Porém existem algumas ressalvas e especificidades dos ambientes analisados.

Os principais problemas detectados no estudo referem-se ao envolvimento da história da marca, não só de origem, mas também da sua concepção, motivação, seus projetos sociais, estarem de alguma forma evidenciados no ponto de venda para que o consumidor se sinta parte daquela marca, vivenciando-a além dos seus produtos.

Considerando, exemplificativamente, que a marca foi construída e desenvolvida ao longo dos anos em Santa Catarina, acredita-se que ressaltar este aspecto, contar sua história através do ponto de venda, pode atrair novos compradores que valorizam por exemplo, empresas regionais. Para Carvalhal (2014), se esta conexão for genuína e verdadeira, pode se tornar uma estratégia, agregando um pacote de significados já existentes. Segundo o mesmo, sabe-se que é necessário ter abordagens diferentes em diferentes praças, manter a identidade e realçar outros elementos de acordo com cada mercado.

Talvez este não seja o intuito da Cia.Hering que tem como objetivo expandir-se no mercado, mas olhando de forma local, nos ambientes estudados, manter sua identidade, porém agregar mais aspectos que remetem a sua origem, poderia trazer novos consumidores para o seu universo. Assim como atrair os consumidores que dão preferência por empresas que tem sua responsabilidade social bastante clara.

Para Carvalhal (2014), o consumidor gosta mais das marcas quando se aprofunda nas suas histórias, quando se é contado do que gostam, do que fazem, grandes marcas sempre estão cercadas de grandes histórias. Assim conseguem transmitir sua personalidade, estilo de vida, declarar seus valores, crenças e objetivos. É desta forma que elas alcançam o coração das pessoas.

Referindo-se propriamente aos elementos que compõe a atmosfera do PDV em relação a percepção do DNA da marca, os revestimentos e mobiliários das lojas analisadas apresentaram DNA ausente perante a percepção do consumidor. Entende-se que o ambiente foi projetado para se neutralizar em relação aos produtos, porém tanto os revestimentos, como os mobiliários que se apresentaram indiferentes ou sem identidade clara para o consumidor, poderiam apresentar-se de forma única, explorando os sentidos através das texturas. Desta forma, buscar 
diferenciar-se do comum. Poucos profissionais dão atenção para este aspecto. Inclusive há pouco referencial teórico abordando este assunto, porém sabe-se que espaços únicos e incomuns, com experiências sensoriais ou visuais singulares, reforçam a identidade e o estilo da marca. Mais envolvimento, mais memórias positivas para a marca, mais fidelização, e por consequência mais vendas.

Sobre o layout da loja, este se apresentou satisfatório, porém através da observação notou-se que poderia ser dada mais atenção para alguns posicionamentos de expositores de paredes, que ficaram prejudicados, bem como a falta de planejamento de espaços de estar na loja B. Para Bailey e Baker (2014), o layout perfeito de um ambiente de loja, deve refletir a aparência geral da marca, mas é importante também levar em consideração a estética do espaço comercial e o conforto do cliente.

A comunicação visual mostrou-se bastante efetiva no ponto de venda. A maior parte dos consumidores reconheciam, e identificavam os peixes do logotipo no ambiente. Quando estes consumidores explanavam sobre as percepções provindas do ambiente e das vitrinas, na maior parte das respostas, os compradores identificavam a marca facilmente devido a presença do logotipo no ambiente.

A iluminação de forma geral apresentou-se como agradável no ambiente, segundo o consumidor. Porém diante da percepção do funcionário, a iluminação se mostrou como negativa, por apresentar um excesso de iluminação. Cabe aos projetistas verificarem e criarem soluções para este desconforto, que pode consequentemente afetar o seu funcionário de forma negativa, refletindo no tratamento com o cliente e consecutivamente na imagem da loja.

No que se refere a identidade sonora da marca, a maior parte dos usuários, consumidores e funcionários, avaliou como agradável o som ambiente, pelo fato das músicas não se repetirem e apresentarem um volume baixo. Porém em alguns dias, na loja B, o volume encontrava-se demasiadamente baixo a ponto das pessoas não o perceberem, prejudicando a experiência de compra.

Morgan (2011), acredita que é necessário pensar se a música combina com o estilo dos produtos e do cliente. Assim, considerando que a marca em análise, tem como "DNA" casual e busca atingir um público jovem, a rádio com músicas atuais, atende a proposta da marca para atrair este público. 
Sobre a falta de identidade olfativa da marca, observou-se que muitos consumidores acreditam que dependendo do aroma escolhido, "poderia irritar", ou "ser enjoativo", o que coincide com a opinião dos funcionários.

Referente aos estudos, feitos pela própria marca, explanado pela consultora de franquias regional, em conversa informal, no que se refere a inserção de aroma no ambiente, seria muito complexo combinar o aroma com as estações do ano, que são fonte de inspiração para lançamento de novos produtos. Porém, acredita-se que um maior envolvimento da marca através de novos sentidos, pode potencializar o posicionamento da marca na mente dos consumidores e aumentar a permanência do mesmo no ambiente.

Gatto (2007) menciona que o intuito da utilização olfativa no ambiente, tem como objetivo envolver o consumidor a permanecer mais tempo no ambiente, segundo o autor estudos feitos mostram que os consumidores expostos a uma atmosfera olfativa perceberam estar menos tempo no ambiente do que de fato ocorria, o que não aconteceu com consumidores que não estavam expostos a um aroma. Outro fator mencionado pelo autor, foi em razão do humor do funcionário no ambiente de venda, devido as longas jornadas de trabalhos muitas empresas têm usado o aroma como terapia e melhoria do ambiente de trabalho.

$\mathrm{Na}$ área das vitrinas, percebe-se que o setor é pouco explorado, entendese que com tantas franquias o valor destinado as vitrinas é reduzido, porém, esta área é similar ao cartão de visitas da empresa, local onde os produtos ganham destaque, e onde a marca comunica seu público alvo e sua intenção. Em observação aos ambientes de venda analisados, muitos dos consumidores não observavam a vitrina antes de acessar a loja, talvez pelo fato de já serem consumidores ativos, talvez pela falta de atratividade. Uma vitrina segundo Bailey e Baker (2014), é como a capa de um livro: o seu design, o estilo, o conteúdo e a narrativa, devem atrair o observador para dentro dela.

Quando observado e analisado sobre o produto da marca, muitos consumidores ressaltaram que reconheciam o mesmo, devido as suas características, como estampas e cores das peças de vestuários. No ambiente físico da loja os mesmos se destacavam, pois, a cartela de cor neutra para as paredes e piso escolhidos pelos projetistas, não competia com as cores dos produtos, ressaltando as suas características, fator esse positivo que foi mencionado e percebido pelos compradores. 
Percebe-se através dos resultados encontrados que é determinante para elaboração de qualquer projeto de arquitetura comercial, que o profissional de arquitetura conheça sobre o DNA de marca, compreenda o tipo e as características do produto a ser comercializado e o público pretendido afim de alinhar a imagem pretendida pela empresa no ponto de venda ao seu projeto.

Projetos executados com pouco ou nenhum tipo de conhecimento sobre as características e particularidades das atividades comerciais, assim como dos serviços envolvidos tendem a encontrar mais dificuldades de fidelização de clientes e reconhecimento pelo público. (Gurgel, 2005)

Portanto cabe ao projetista da loja em conjunto com outros profissionais envolvidos com a marca, identificar as características relevantes e importantes a serem enfocadas no projeto de arquitetura comercial.

\section{Considerações Finais}

Foi objetivo do estudo investigar a percepção dos elementos da atmosfera do ponto de venda perante os seus usuários - funcionários e consumidores, em relação ao "DNA da marca".

A marca analisada se mostrou perante o seu consumidor como confiável e acessível, apresentando um ambiente agradável e propício a compras. Porém, ainda oferece poucas experiências sensoriais e inovadoras no ponto de venda.

Entende-se que de todos os canais de venda, o físico é o que tem o maior poder de construir a marca (Carvalhal, 2014). Quanto mais o projeto de arquitetura e visual merchandising em conjunto com ações de outros profissionais envolvidos com a marca, se aproximar do "DNA de marca" da empresa, e buscar o bem-estar do seu consumidor e funcionário, maior será o vínculo do indivíduo com a marca.

A verificação do "DNA de marca" nas lojas estudadas diante da percepção do seu consumidor - funcionários e consumidores, trouxe subsídios importantes para compreender, que assim como nós, é ao decorrer da vida que as marcas se constroem. Marcas bem-sucedidas se aceitam como ambiente vivos, continuam se adaptando às mudanças de mercado, segmento, cultura, economia, mas sem abrir mão da sua essência. O apego ao significado é de onde nascem construções consistentes e coerentes. 
Por fim, considera-se que o objetivo proposto foi contemplado e que o relato do estudo destaca a importância de alinhar os valores e as características do "DNA de marca" juntamente com o projeto arquitetônico e de visual merchandising de ambientes de venda. Assim, espera-se que o estudo explanado neste trabalho contribua para que os profissionais de arquitetura e visual merchandisers construam espaços comerciais mais condizentes com o "DNA de marca" e por consequência atendam as expectativas de seus usuários e stakeholders.

\section{Notas:}

1 AMARO, Edson. Entrevista concedida a revista propaganda sobre o DNA da marca Hering. Disponível em: <http://www.ciahering.com.br/novo/pt/noticias/nosso-diretor-de-marcas-e-entrevistadopela-revista-propaganda> Acesso em 25 de outubro de 2016

\section{Referências}

BAILEY, Sarah; BAKER, Jonathan. Moda e Visual Merchandising. São Paulo: Gustavo Gili, 2014.

BLESSA, Regina. Merchandising no Ponto de Venda. São Paulo: Atlas, 2008.

BAKER, Julie. The role of the Environment in marketing services: The consumer perspective. The services challenge: Integrating for competitive advantage (pp. 7984) Associação Americana de marketing.

BARDZIL, James R.; ROSENBERGER III, Philip J. Atmosphere: Does It Provide Central Or Peripheral Cues?", in AP - Asia Pacific Advances in Consumer Research. Russel Belk and Ronald Groves, Provo, UT : Association for Consumer Research. V. 2. P.73 - 79, 1996. Disponível em: < http://www.acrwebsite.org/search/viewconference-proceedings.aspx?ld=11536>. Acesso em 28 fevereiro de 2015.

BITNER, Mary Jo. Servicescape: The Impact of Physical Surroundings on Customers and Employees. Journal of Marketing. v. 56. p. 57-71, 1992.

CARVALHAL, André. A moda imida a vida: como construir uma marca de moda. São Paulo: Estação das Letras; Rio de Janeiro: Editora Senac, 2014.

COBRA, Marcos. Administração de Marketing no Brasil. 3 ed. Rio de Janeiro: Elsevier, 2009.

GURGEL, Miriam. Projetando espaços - Guia de Arquitetura de Interiores para espaços comerciais. São Paulo: Editora SENAC, 2005.

GATTO, Stefania del. L'atmosfera del punto vendita quale strumento di differenziazione dell'insegna: uma verifica empírica delgli effeti della variabile olfativa. Anais del Congresso Internazionale Le Tendenze del Marketing.Venezia, 2002. 
KOTLER, Philip. Atmospherics as a marketing tool. Journal of Retailing. v. 49, p.4864, 1973-1974

LOPES, Dayane Alves; GOMEZ, Luiz Salomão Ribas. Os 4 elementos do DNA de marcas: emoção, resiliência, técnica e mercadologia. CONFERÊNCIA INTERNACIONAL EM DESIGN E ARTES GRÁFICAS - CIDAG, 2, 2012, Lisboa. Anais. Lisboa: ISEC, 2012

MINAYO, Maria Cecilia de Souza. Pesquisa Social: Análise qualitativa: teoria, passos e fidedignidade. Ciência \& Saúde Coletiva, 17(3):621-626, 2012.

MICHAELIS. Dicionário Online. 2016. Disponível em: <http://michaelis.uol.com.br/>. Acesso em: 16 outubro 2016.

MORGAN, Tony. Visual Merchandising: Vitrines e interiores comerciais. Barcelona: Editorial Gustavo Gili, 2011.

NEILSON, Gary L.; PASTERNACK, Bruce A. Resultados: mantenha o que está certo, corrija o que está errado e obtenha um ótimo desempenho. Rio de Janeiro: Rocco, 2009.

RIES, All ; TROUT, Jack. Posicionamento: a batalha por sua mente. São Paulo: M. Books do Brasil Ltda, 2009

SOLOMON, Michael R. O comportamento do consumidor: comprando, possuindo e sendo. 9 ed. Porto Alegre: Bookman, 2011

STODIECK, Walter Flores. Brand DNA TOOLKIT: Aplicação do Design em uma metodologia de branding. 2014. Dissertação (Mestrado em Design e Expressão Gráfica) - Programa de Pós Graduação em Design e Expressão Gráfica. Universidade Federal de Santa Cataria. Florianópolis: 2014.

ZORRILLA, Pilar. Nuevas tendencias en merchandising: Generar experiencias para conquistar emociones y fidelizar clientes. Distribuición y Consumo, set-out, 2002, p. 13-20. 